\title{
カテーテルによる耳管機能検査の再現性
}

\author{
守田 雅 弘
}

\section{Reliability for Clinical Use of Sonotubometry and Insufflation Test with Tubal Catheter}

\author{
Masahiro Morita \\ (Osaka University)
}

Using a tubal catheter, we examined the test-retest reliability of sonotubometry and of the tubal air insufflation test in normal subjects. The tubal insufflation test was evaluated by the measurement of tubal opening pressure and sound pressure during air insufflation with a tubal catheter. At the initial examination a tubal catheter was inserted into the pharyngeal tubal orifice under fiberscopic inspection. On another day, the second examination was done in the same way but without fiberscopic inspection.

The mean values of the test results were the same on both days, except that the baseline sounds measured by sonotubometry, were slightly higher on the second day. A comparison of the results of sonotubometry tests showed that a correlative rate between each value on the first day and on the second day in sound amplitude was significantly higher both before $(\mathrm{p}<0.10)$ and after air insufflation $(\mathrm{p}<0.01)$, and the correlative rate in sound duration was higher only after air insufflation $(p<0.01)$. However, no significant correlations were found in the results of air insufflation test.

We conclude that sonotubometry with a tubal catheter is a more reliable and stable method of evaluating tubal function than the tubal air insufflation test.

Key words: eustachian tube, tubal function, sonotubometry, tubal insufflation

\section{はじめに}

慢性中耳炎や滲出性中耳炎などの中耳疾患の 大部分は耳管機能障害に起因するといわれて拉 り, これらの疾患の診断や治療に際して的確な 耳管機能の把握が必要となっている．このため 様々な耳管機能検查が行われているが，これら の検査結果を評価するにあたって，検査結果に 偽陽性や偽陰性を生じることがあり，普遍的な 検査法の開発にはいまだ到っていない，著者 ら 1)2) がすでに報告した耳管カテーテルを用い
た音響耳管検査は，耳管咽頭口部より直接負荷 音源を耳管内へ誘導でさることから従来よりの 鼻入孔部に負荷音源を扎いた音響耳管検査に比 し, 咽頭雑音や耳管咽頭口部病変の影響を受け にくく，正常耳に执いて20例全例陽性(正常反 応）を示した。しかし，カテーテルを用いた場 合, 耳管通気検査と同様に音響耳管検査でもカ テーテル先端の耳管咽頭口部への固定手技が必 ずしも容易ではないことから，得られた検査結 果の信頼性を検討する必要があると考えられた. 
そこで今回, 著者らはカテーテルを用いた音響 耳管検査および通気度検査の信頼度をみるため, 正常耳をもつ同一被検者に異なった日に本検査 を施行し，検査結果の再現性の有無を検討した.

\section{対象および方法・手技}

耳扣よび鼻疾患の既往がなく，診察所見にて 鼓膜に異常を認めない18歳から38歳をでの10例 17 耳を正常耳とし対象とした。音響耳管検査拉 よび通気検査を施行するにあたって, 両側鼻腔 内の総鼻道に面する下鼻甲介拉よび鼻中隔粘膜 面に $4 \%$ キシロカインを綿棒にて軽く塗布した 後, 検査側鼻腔より原則として0号の耳管カ テーテルを挿入しいわゆる耳管通気の要領で鼻 咽腔へ固定した.この時に対側鼻腔より軟性内
視鏡を挿入しカテーテル先端部が耳管咽頭口部 から約 $1 \mathrm{~cm}$ 耳管峡部よりの深さに挿入される のを確認した。検査装置は永島医科器械製の ET-1000の基礎モデルを用いた。すなわち， 耳管カテーテル基部に $1 / 3$ オクターブ $8 \mathrm{kHz}$ のバンドノイズを発する音源を置き，送音しな がらまず自発的に 3 回の器下運動を行ってもら らことにより耳管の開閉をみる音響耳管検査を 施行したのち，カテーテルを同じ位置に挿入し たままで通気検查を 1 回につき約 $10 \sim 15$ 秒間, 数回施行し, その直後, 通気時と同じカテーテ ルの位置で再び音響耳管検査を施行した。なお 本装置のブロックダイアグラムおょよび検査手技 ・方法についての詳細は著者の他論文 ${ }^{122)}$ に譲

\section{（I）能動的耳管開大能(音響耳管検査)}

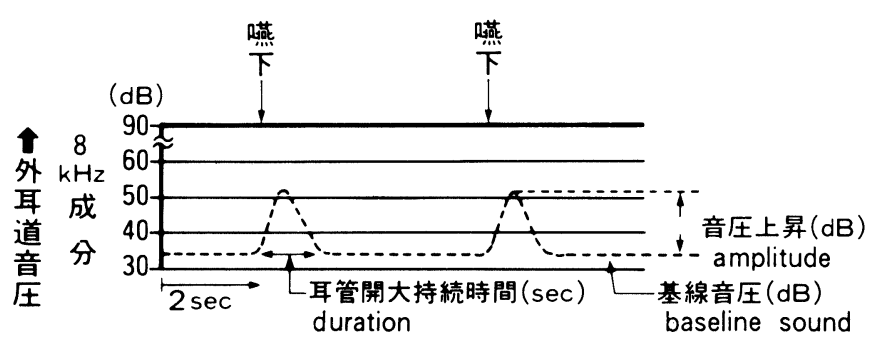

\section{（II）受動的耳管開大能(通気度)}
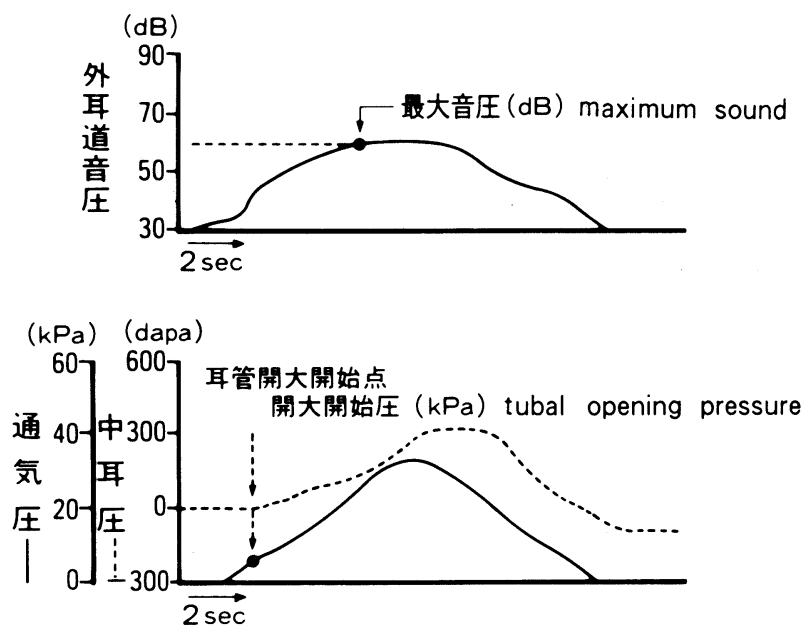

図1 カテーテルを用いた耳管機能検査

I 能動的耳管開大能 (音響耳管検查) 㧍よび II 受動的耳管開大能 (耳管通気度検査)の検査結果の判定方法. 
る.

曣下による能動的耳管開大能をみる音響耳管 検査結果の判定は，外耳道部に打沙る負荷音源 である $8 \mathrm{kHz}$ 成分の音圧変化より行った1). 判 定に用いたパラメーターは, 非燕下時すなわち 安静時の外耳道部の音圧である基線音圧 baseline sound $(\mathrm{dB})$, 燕下時に一致した基線音 圧からの音圧の上昇分である音圧上昇 amplitude $(\mathrm{dB})$ ，音圧が基線音圧よりぬ上昇している時間 を示す耳管開大持続時間 duration (sec) (以下, 耳管開大時間)で, $5 \mathrm{~dB}$ 以上の音圧上昇が 3 回 の曣下の内 2 回以上認められたものを陽性とし た(図 1 上). 耳管の受動的開大能を調べる耳管 の通気度の検査では, 通気圧を手動にて約 3 $\mathrm{kPa} / \mathrm{sec}$ の速度で上昇させていくと外耳道部の コンプライアンスが低下し始める点があり, こ れを中耳に空気が流入し始めた点と考兄この時 の通気圧を耳管開大開始圧とした。そのまま通 気圧を徐々に上げて行くと外耳道部の音圧は最 大となり，この時の音圧を最大音圧とした(図 1 下).

これらの一連の検査を, 再現性をみるために 最低 2 日以上，最高 2 週間の間隔をあけて，軟 性内視鏡を挿入しなかった以外は同様の手順で 再度検査を同一被検者に施行した。な拉，初回 日の検査と 2 回目の日の検查は, すべて同一検
者が施行した。

\section{結果}

音響耳管検査の場合は通気前と通気後に，通 気度検査の場合は一連の通気操作での初回通気 時と, 初回の通気により耳管内や耳管咽頭口部 の粘液や分泌液などが排除されて条件が比較的 安定した，いわゆる定常状態の耳管になったと 思われる 3 回目の通気時とに分けて, 各々の検 査結果を初回日と 2 回目の日の検査時とで比較 した.

音響耳管検査では, 通気前の陽性例は初回日, 2 回目の日の検查時とも 17 耳中 15 耳 り , 通気 後は初回日, 2 回目の日とも 17 耳中 16 耳陽性で あった．な拉，音響耳管検査にて通気後陰性例 は通気前には陽性を示したことから，今回対象 となった例では, 初回日と 2 回目の日の検査時 のどちらに扣いても，通気前後とも陰性を示し たものはなかった．表 1 に示す音響耳管検査の 陽性例の検查結果の平均值では, 通気前あるい は後の音圧上昇, 耳管開大時間について, 初回 検查時と 2 回目の再検査時とで比較したところ 明らかな差は認めなかった $(\mathrm{t}$ 検定にて，耳管 開大時間の通気後の場合 $\mathrm{p}<0.10$ ，それ以外は いずれも $\mathrm{t}$ 検定にて $\mathrm{p}>0.10$; 表 1$)$. 同様以 基線音圧について比較してみると，通気前の場 合 2 回目の検査時に $52.5 \mathrm{~dB}$ と初回時の 44.6

表 1 カテーテルを用いた耳管機能検査

音響耳管検査拉よび耳管通気度検査結果の平均値の比較

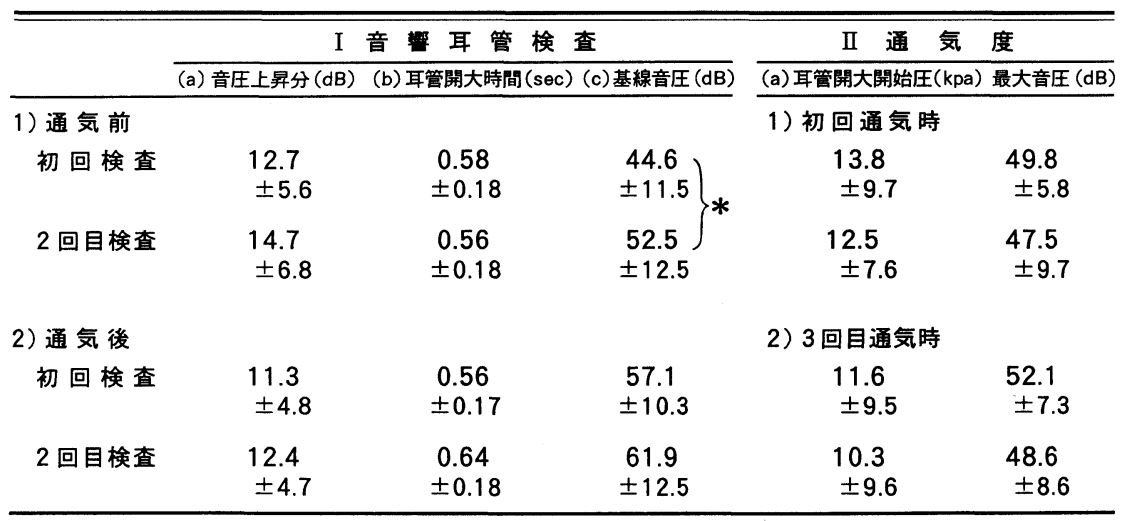

$*: \mathrm{p}<0.05(\mathrm{t}$ 検定 $)$ 
$\mathrm{dB}$ と比べて明らかに高くなった $(\mathrm{t}$ 検定にて $\mathrm{p}<0.05)$ が，通気後の場合は初回と 2 回目と の間で有意差は認めなかった $(\mathrm{t}$ 検定にて $\mathrm{p}>$ 0.10). カテーテルによる通気検査すなわち通 気度についても同様に検査結果の平均值でみる と, 一連の通気操作での初回通気時と定常状態 である 3 回目の通気時のいずれとも耳管開大開 始圧や最大音圧には初回日と 2 回目の日の検査 結果との間で特に差は認めなかった $(\mathrm{t}$ 検定に
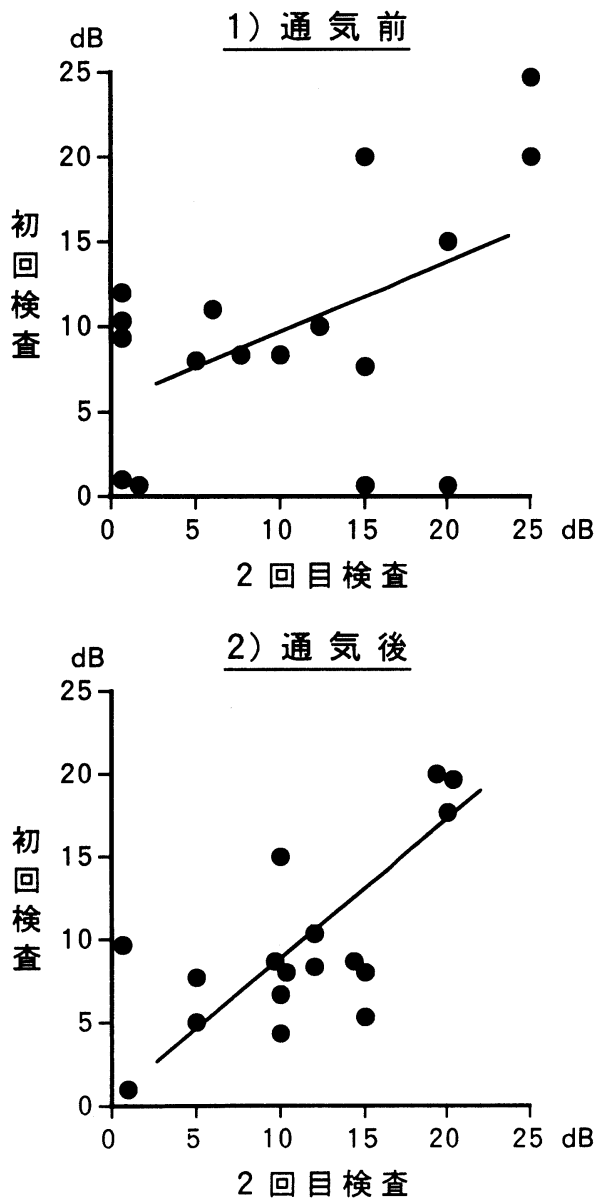

図 2 カテーテルを用いた音響耳管検査の音 圧上昇

初回日と 2 回目の日との検查結果の相関 (通 気前; $\mathrm{r}=0.481882, \mathrm{p}<0.10$, 回㷌直線 $\mathrm{Y}=$ $4.69632+0.582803 X$. 通気後 $r=0.83758$, $\mathrm{p}<0.01$, 回㷌直線 $\mathrm{Y}=2.62971+0.869376$ $\mathrm{X})$. $\tau \mathrm{p}>0.10)$.

次に音響耳管検査と耳管通気度の各々のパラ メーターごとに個々の例について初回日と 2 回 目の日の結果の相関度を同一被験者でみた。通 気前後で分けてみると, 音響耳管検査の音圧上 昇(図 2 )の場合, 初回日と 2 回目の日の検査結 果との間で通気前は相関傾向 $(r=0.481882$, $\mathrm{p}<0.10$, 回帰直線 $\mathrm{Y}=4.69632+0.582803 \mathrm{X}$ ) を認め, 通気後では明らかな相関 $(r=0.83758$,

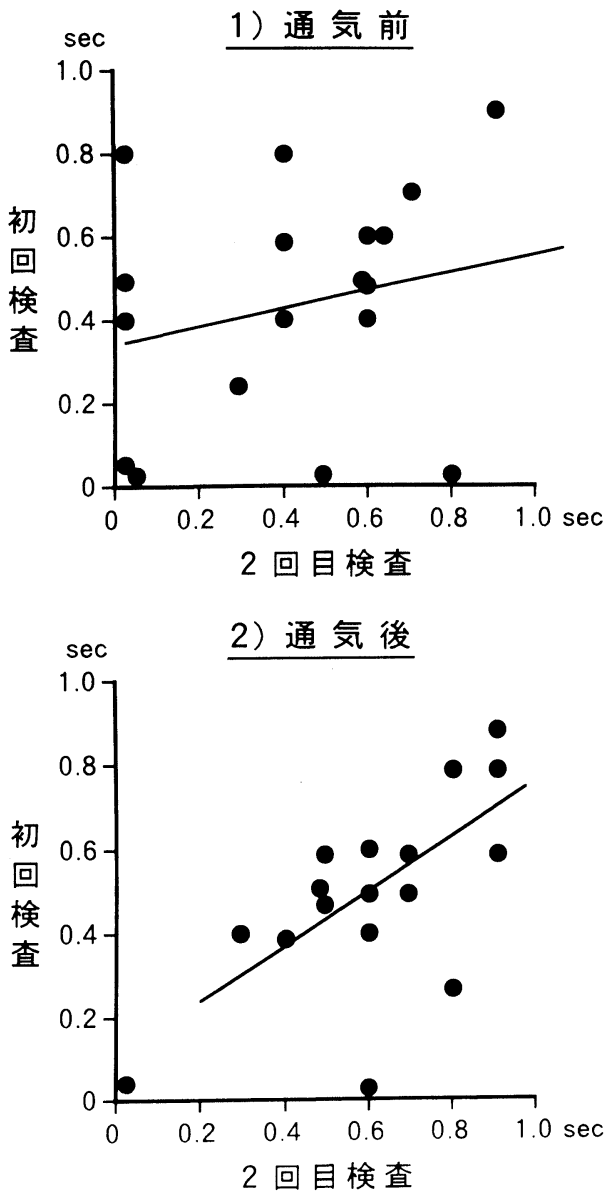

図 3 カテーテルを用いた音響耳管検査の耳 管開大時間

初回日と 2 回目の日との検査結果の相関 (通 気前; $r=0.255121, p>0.10$, 回帰直線 $\mathrm{Y}=$ $0.285141+0.260348 \mathrm{X}$. 通気後 $; \mathrm{r}=$ $0.775496, \mathrm{p}<0.01$, 回帰直線 $\mathrm{Y}=0.144022+$ $0.880434 \mathrm{X})$. 
$\mathrm{p}<0.01$, 回帰直線 $\mathrm{Y}=2.62971+0.869376 \mathrm{X})$ を認めた。同様に耳管開大時間でみると（図 3)， 初回日と 2 回目の日の検査結果との間で通気前 はまったく相関を認めなかった $(\mathrm{r}=0.255121$ ， $\mathrm{p}>0.10$, 回帰直線 $\mathrm{Y}=0.285141+0.260348 \mathrm{X}$ ) が, 通気後では明らかに相関 $(r=0.775496$, $\mathrm{p}<0.01$, 回㷌直線 $\mathrm{Y}=0.144022+0.880434 \mathrm{X}$ ) を認めた。音響耳管検査の非嚥下時の音圧であ る基線音圧で同様に初回日と 2 回目検査日との
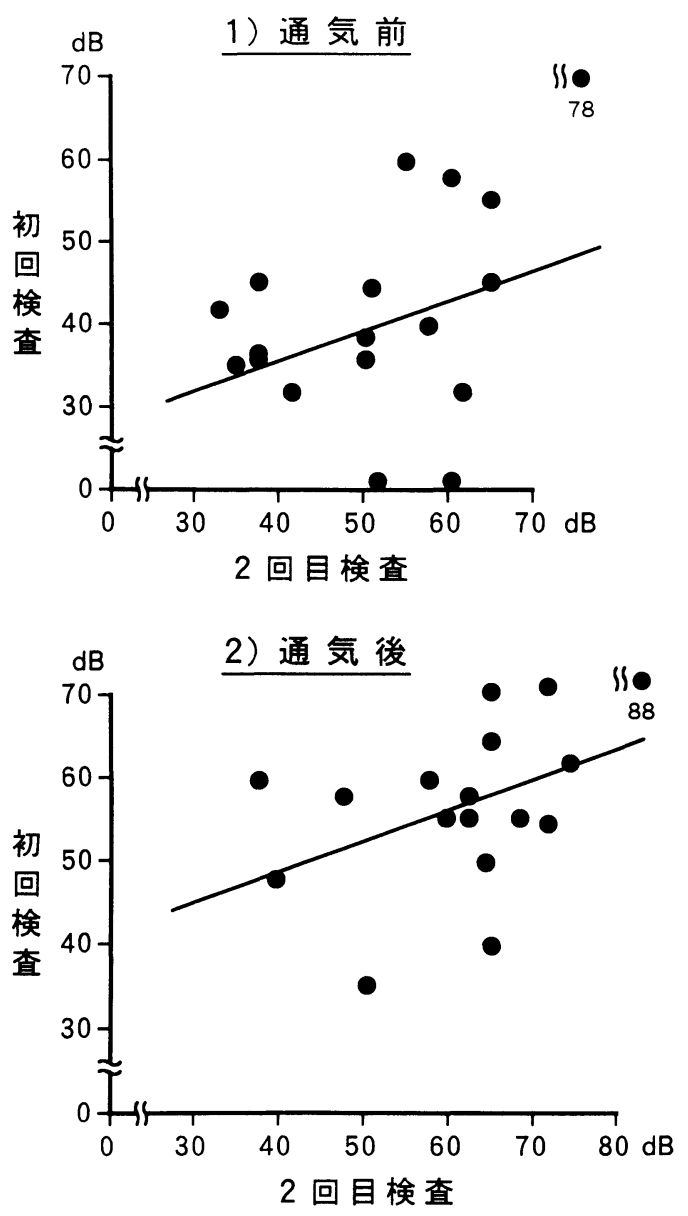

図 4 カテーテルを用いた音響耳管検査の基線音 生

初回日と 2 回目の日との検査結果の相関(通気前; $\mathrm{r}=0.508298, \mathrm{p}<0.10$, 回帰直線 $\mathrm{Y}=29.713+$ $0.532157 X$. 通気後 $; r=0.461329, p<0.10$, 回 㷌直線 $\mathrm{Y}=30.0456+0.55739 \mathrm{X})$.
結果を比べてみた場合, 通気前 $(\mathrm{r}=0.508298$, $\mathrm{p}<0.10$, 回帰直線 $\mathrm{Y}=29.713+0.532157 \mathrm{X}$ ), 通気後 $(r=0.461329, p<0.10$, 回帰直線 $\mathrm{Y}=$ $30.0456+0.55739 X)$ とも明らかな相関は認め なかった(図 4 ).

耳管通気度の耳管開大開始圧では一連の通気 操作での初回の通気時および定常状態の通過時 とも, 初回日と 2 回目の日の検査結果との間で 全く相関は認めなかった（初回通気時; $r=$
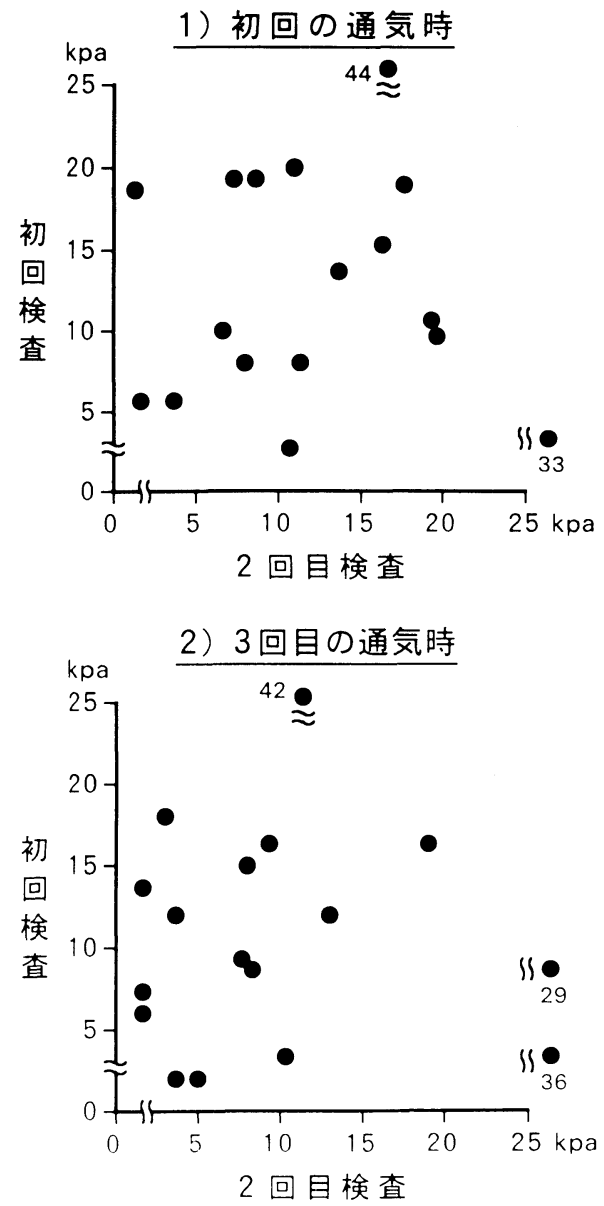

図 5 カテーテルを用いた耳管通気度検査の 耳管開大開始圧

初回日と 2 回目の日との検査結果の相関(初 回通気時 $; \mathrm{r}=0.0136835, \mathrm{p}>0.10$, 定常状態 の通気時 $; \mathrm{r}=-0.170869, \mathrm{p}>0.10)$. 
$0.0136835, \quad \mathrm{p}>0.10$, 定常状態通気時 $; \mathrm{r}=-$ $0.170869, \mathrm{p}>0.10$, 図 5 ). 同様に耳管通気度 検査の最大音圧について初回日と 2 回目の日の 検査結果を比較した場合, 初回の通気時掞よび 定常状態の 3 回目の通気時とも全く相関を認め なかった(初回通気時; $\mathrm{r}=0.262512, \mathrm{p}>0.10$, 定常状態の通気時 $; r=0.25393, p>0.10$, 図 6 ).

\section{考案}

カテーテルを耳管咽頭口へ挿入するにあたっ て 1 回目は軟性内視鏡を用いて直視下で確実に
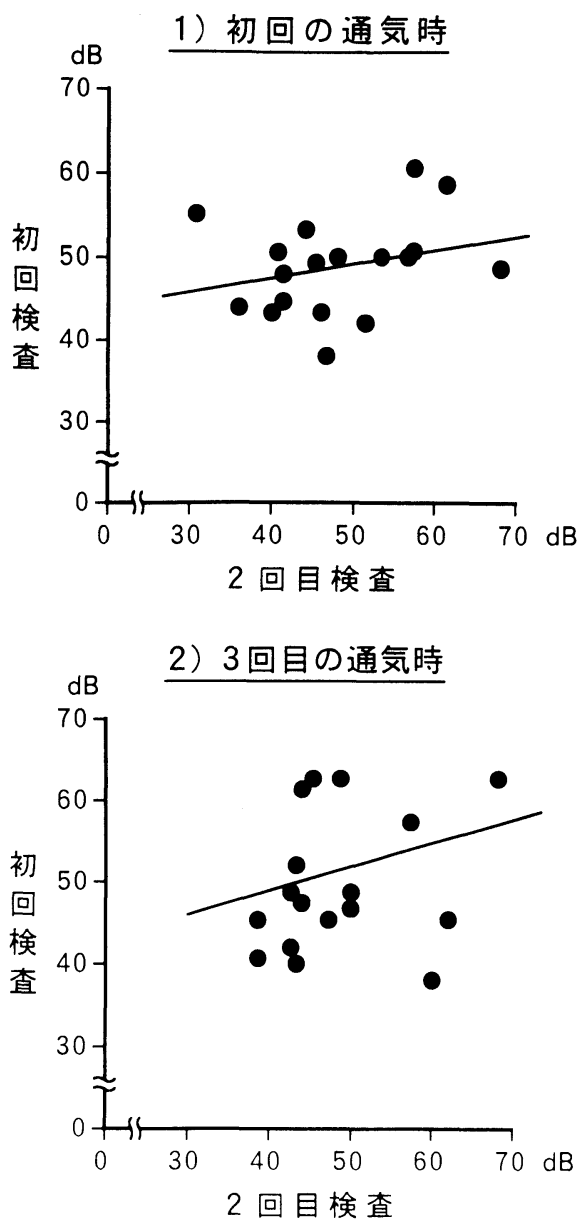

図 6 カテーテルを用いた耳管通気度検査の 最大音圧

初回日と 2 回目の日との検查結果の相関(初 回通気時 $; r=0.262512, p>0.10$, 定常状態 の通気時; $r=0.25393, p>0.10)$.
先端を耳管咽頭口へ誘導固定し，2 日以上あけ た 2 回目は従来の耳管通気と同様に非直視下に カテーテルを挿入固定することにより検査結果 の再現性の有無をみることでその信頼性および 有用性の検討を行った，その結果，音響耳管検 査と通気度とに拈いて初回と 2 回目の各々の平 均值を比較した場合 (表 1 ), 通気前の基線音圧 が 2 回目の検査時に有意に高くなった以外は平 均値に拈いては明らかな差は認めず, 検査結果 の全体の分布には差は認めなかった. 2 回目の 検査時に基線音圧が高くなった理由としては, 2 回目の検査が 1 回目の検查から比較的近い日 の $2 \sim 3$ 日後に行われている症例で高くなって いるものがあり, 1 回目の検查時の耳管通気に より耳管内の粘液や分泌液が飛ばされた結果生 じていることが考えられる。

個々の例について比較してみると(図 $2 \sim 6$ ), 音響耳管検查では通気を行わない状態では音圧 上昇に执いて軽度の相関を認めたのみで, 通気 後の同様の比較では, 基線音圧以外の與下時の 音圧上昇と耳管開大時間に执いて, 初回日と 2 回目の日の検査時との間に明らかな相関を認め た.このことから通気を行わない状態では軟骨 部耳管内に貯留粘液や粘膜の被りがあるため3), 燕下による外耳道部での音圧上昇の再現性に比 較的乏しく通気後には粘液や粘膜の被りなどが 除去されるため明らかに音響耳管検査としての 再現性が高くなったと考えられた。一方，耳管 通気度では初回時执よび定常状態に㧤いても初 回日と 2 回目の日の検查時との間に相関は全く 認めなかった。すなわち，カテーテルによる耳 管通気度検査では, 粘液や粘膜の被りなどが除 去されたと思われる定常状態の 3 回目の通気時 に拈いても違った日に行った場合，耳管開大圧 や最大音圧の再現性は乏しいと考えられた。

ティンパノメトリーやカテーテル耳管通気検 查などの従来より一般的に行われている耳管機 能検査だけでは, 耳管開放症やフロッピーチ ューブはもとより滲出性中耳炎に执いても耳管 機能異常の病態把握は困難であるといわれてい 
$3^{4)}$. 最近では圧平衡機能検査や音響耳管検査 などの新しい検査法が普及し初め, 病態により そくした耳管機能異常の診断が可能となりつつ ある．音響耳管検査で鼻入孔部より音源を負荷 する従来からの方法は，その検查手技が比較的 容易であり，同一人に括ける再現性にも比較的 優れて扮り，被検者への侵襲もきわめて少ない 事が報告されている5)6)。しかし，その一方， 偽陽性や偽陰性例が比較的多く定性的検査の域 を出ていないことも報告されている7).この従 来からの方法で誦陽性や偽陰性例が多いことは, 音響耳管検査で鼻入孔部に音源をおいた場合は 鼻腔・鼻咽腔・耳管咽頭口部の解剖学的形態あ るいは分泌液や貯留粘液などの局所反応にも影 響され易(8)ことより推察でさる．著者ら ${ }^{12)}$ の提唱しているカテーテルを用いた音響耳管検 査では, カテーテル先端部が耳管咽頭口部へ確 実に挿入されていさえすれば，これらの鼻腔形 態や耳管咽頭口部病変などの影響を受けにくく, 耳管通気操作や従来の音響耳管検査を組み合わ せることで定性的検査以上の有用性があると思 われた。ただし，今後の課題として，従来の鼻 入孔部湆源を置く音響耳管検査の再現性と今 回のカテーテル音響耳管検査の再現性との差を 同一個体で検討するべきと思われる．

今回の著者らの報告では初回日の検査時にの 久軟性内視鏡による明視下にカテーテル先端部 を耳管咽頭口部へ確実に挿入したが，初回の日 と 2 回目の日の検査結果を比較した場合, 音響 耳管検査では通気後に特に再現性が高くなった のに対して, 通気度検査では定常状態になって も再現性の乏しさは変わらなかった．特にこの 通気度検查にて再現性が不良であった理由とし て，先ず第 1 亿考えなければならないのは，初 回日と 2 回目の日との間や同じ日の一連の検査 施行中でのカテーテル先端部のずれや閉塞など の検査手技上の問題がある. 一連の検査の流れ の中で同じカテーテル固定位置で続けて施行さ れた通気度検查と音響耳管検査に招いて, 初回 日と 2 回目の日との間で前者の通気度検査結果
では低い再現性を示した一方で, 後者は通気後 に高い再現性を示した．同じ条件で行われたこ の 2 つの検査法に括ける再現性の違いは検査手 技の問題よりも，物理的な諸条件に変化を起こ しやすく，かつわずかな粘膜腫脹などに影響さ れやすい通気時の空気圧を測定するか，侵襲の 汪とんどない負荷音源の音圧を通気後の修飾因 子の少ない条件で測定するかの検査法の性格上 の問題の差に起因すると考えられた。ティンパ ノグラム以外の耳管機能をみる検査法は, 従来 よりある耳管通気検査はもちろんのこと，最近

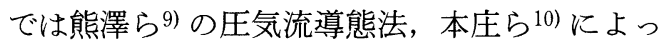
て改良を加えられた加圧減圧テスト，守田ら ${ }^{3)}$ 大久保ら ${ }^{4)}$ の音響耳管検査などが報告改良され て診断に役立つようになってきている。どの検 査法もその検査結果が耳管機能障害の病態を的 確に反映しらる反面, 疾患によっては 1 つの検 査法だけでは判定困難な場合も多い。そこで種 種の検査法を組み合わせることが必要となって くる．この場合，得られた検查結果に信頼性が あることが最低の必要条件であり，鋭敏性 sensitivity や特異性 specificity が高い検査法であ ればあるほどより損なわれ易い再現性の検討を する必要があると考光られた。

今回，著者らが報告したカテーテルによる音 響耳管検査法 (カテーテル音響耳管検査)は，特 に通気直後において非常に強い再現性を示した。 一方，カテーテルによる耳管通気度検査に执い ては, 今回, 従来の主観的な判定方法を改め著 者ら゙の考案した客観的な判定方法にて, 初回 日は内視鏡下にカテーテル先端部位の耳管内挿 入を確認し検査を施行したにもかかわらず，同 じ条件で施行した音響耳管検査の場合と違って 2 回目の日の検査結果の再現性が低かった。こ のことは，耳管カテーテルによる耳管の開大開 始圧などの耳管通気度の測定が，検者の技術は ともかくとして，被検者の体調や局所の生理的 反応などの諸条件に微妙に影響される可能性が あることを示唆するものである，従って，耳管 カテーテルによる通気度検査は, 単独では耳管 
機能検査としての意義が少なく，カテーテルを 用いた音響耳管検查などの他の検査と組み合わ せて行ら必要があると考えられた。また，この ことより日常臨床に扮けるカテーテルによる耳 管通気は, 検査目的以外飞も今後治療手段とし ての有用性も同時に検討されていく必要がある と思われた。

カテーテルを用いた音響耳管検査は，鼻入孔 部よりの従来法と組み合わせて行うことで疾患 耳に拈いてもその病態診断に役立つことが示唆 されて扣り 11$)$, 今後の耳鼻咽喉科医の日常診療 においても治療や診断補助目的のいわゆる力 テーテル通気と同様に十分資することができる ものと思われる。

\section{まとめ}

1) カテーテルを用いた音響耳管検査および 通気度検査の信頼度をみるため，正常耳をもつ 同一被検者に初回日は軟性内視鏡にてカテーテ ル先端部の位置を確認しながら本検査を施行し, 異なった日の 2 回目の検査結果と比較すること で再現性の有無を検討した.

2 ）検査結果の平均値でみると，音響耳管検 查の基線音圧が 2 回目の日の検査時に高くなっ たが，その他の音圧上昇，耳管開大時間，耳管 通気度検查の耳管開大開始圧, 最大音圧には初 回検査時と 2 回目の再検査時とで比較したとこ ろ明らかな差はなかった。

3 ）個々の例について初回日と 2 回目の日と の音響耳管検查結果の相関度をみると, 通気前 では，音圧上昇に有意傾向を認めたのみで耳管 開大時間には有意な相関はなかった。しかし， 通気後の場合, 音圧上昇, 耳管開大時間とも 1 $\%$ 以下の危険率で初回日と 2 回目の日の検査結 果との間で明らかに有意な相関を認めた.

4 ）同様に耳管通気度検査結果の相関度をみ ると，耳管開大開始圧，最大音圧では，一連の 通気操作での初回の通気時拉よび定常状態の通 気時とも, 初回日と 2 回目の日の検査結果との 間で全く相関は認めなかった。

5 ）一連の検査の流れの中で同じ条件下で施
行したカテーテルを用いた音響耳管検査と耳管 通気度検査の再現性の差は検者の技術の問題よ りも，通気時の空気圧を測定するか侵壟のほと んどない負荷音源の音圧を測定するかの検査法 の性格上の問題に起因すると考えられ, 被験者 側の諸条件が耳管カテーテルによる耳管通気度 の検査結果に音響耳管検査の時よりも影響しや すいものと思われた.

6 ）今回, 著者らが報告したカテーテルによ る音響耳管検查は, 通気直後において非常に強 い再現性を示した. このことより，カテーテル 音響耳管検査は今回単独では検査法としての意 義が少ないと思われたカテーテル耳管通気度検 査やさらに鼻入孔部に音源を置く従来法などと も組み合わせて行らことで疾患耳の病態診断や 耳鼻咽喉科の日常診療に十分資することができ るものと思われた。

稿を終えるに臨み，大阪大学 久保 武教授の御校 閲を深謝致します。

本論文の要旨は, 第52回, 53回, 54回の耳鼻咽喉 科臨床学会に扣いて発表した.

\section{参考文献}

1）守田雅弘, 浅井英世, 荻野 壬, 他: 耳管カテー テルを用いた音響耳管検査一鼻入口部法との 比較一. 耳鼻臨床 $83: 1799 \sim 1806,1990$.

2) 守田雅弘 : 耳管機能検查の臨床的意義. 耳鼻臨 床補41：102１12, 1991.

3) Morita $M$ and Matsunaga $T:$ Effects of an anti-cholinergic on the function of patulous eustachian tube. Acta Otolaryngol (Stockh) Suppl $458:$ 63 66, 1988.

4）大久保仁, 渡辺 勇, 石川紀彦, 他: 音響性耳 管検査法 -WIO-01 型試作機使用経験一. 耳 鼻臨床 $77: 1747 \sim 1754,1984$.

5) Virtanen H : Sonotubometry; an acoustical method for objective measurement of auditory tubal opening. Acta Otolaryngol (Stockh) 86 : 93 103,1978.

6）小川 明, 大沼秀行, 稲上憲一, 他 : 加龄に上 る耳管機能の変化. 耳鼻臨床 $80: 1529 \sim 1533$, 1987. 
7) Andreasson L, Ivarsson A, Luttrup S, et al : Eustachian tube function measured as pressure equilibration and sound transmission capacity ; a comparison in healthy ears. ORL $46: 74 \sim 83$, 1984.

8）大久保仁, 渡辺 勇, 渋沢三伸, 他 : 音響耳管 検査法 一-(1)多重記録法による正常值一. 耳鼻 臨床 $77: 1127 \sim 1136,1984$.

9) Kumazawa $T$, Honjo $I$ and Honda $K$ : Aerodynamic pattern of eustachian tube dysfunction. Arch Otorhinolaryngol $215: 317$ $\sim 323,1977$.

10）本庄 藂，牛呂公一，三苫滕吉郎，他：小児滲
出性中耳炎の耳管機能. 耳鼻臨床 77 : 1111 1117, 1984.

11) Morita $M$ and Matsunaga $T$ : Sonotubometry with a tubal catheter as a index for the use of a ventilation tube in otitis media with effusion. Acta Otolaryngol (Stockh) Suppl $501: 59 \sim 62$, 1993.

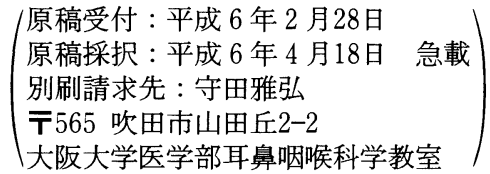

